\title{
Phosphate Adsorption Capacity of Allophane from Two Volcanic Mountains in Indonesia
}

\author{
Tandaditya Ariefandra ${ }^{1,3}$, Naoto Matsue ${ }^{1}$, Eko Hanudin ${ }^{3}$ and Erni Johan ${ }^{1,2}$ \\ ${ }^{1)}$ Department of Environmental Conservation, Faculty of Agriculture, Ehime University, Japan \\ ${ }^{2}$ Department of Material Science and Engineering, Graduate School of Science and Engineering, \\ Ehime University, Japan \\ ${ }^{3}$ Laboratory of Soil Chemistry and Fertility, Gadjah Mada University, Indonesia
}

Received August 26, 2019; Revised January 8, 2020; Accepted 28 January 2020

\begin{abstract}
Allophane is known as clay mineral with high capacity of phosphate adsorption via ligand-exchange mechanism. This study aims to compare the phosphate adsorption characteristics by allophane from Mt. Merapi and Mt. Lawu in relation to its chemical and mineralogical properties. The results of X-Ray Flourescence analysis shows that both allophane samples from Merapi and Lawu have low Si/Al ratio, i.e. 1.18 and 1.16, respectively. Infrared spectral characteristics of the allophane materials indicated that the main adsorption bands appeared at the range of 2700$3700 \mathrm{~cm}^{-1}$ (due to stretching vibration of all hydroxyl $(\mathrm{OH})$ groups), $1400-1800 \mathrm{~cm}^{-1}$ (vibration of HOH deformation), and $650-1200 \mathrm{~cm}^{-1}$ (vibration between the Si-O-Al). Adsorption experiment of phosphate on allophane samples were conducted at initial adsorbate concentration of up to $2.0 \mathrm{mM}$ and at $\mathrm{pH} 4.0$ and 8.0. Phosphate adsorption capacity of allophane shows that both allophane from Merapi and Lawu are categorized as very high in adsorbing phosphate and fit well with the Langmuir adsorption equation. Phosphate adsorption increases with decreasing $\mathrm{pH}$ due to the positive charge sites such as $\mathrm{Al}-\mathrm{OH}_{2}{ }^{+}$in the allophane structure increase. Another reason is the negative charge of phosphate gradually decreases from -2 to -1 with decreasing $\mathrm{pH}$, and the repulsive force between the negatively charged $\mathrm{Si}^{-} \mathrm{O}^{-}$in the allophane structure and phosphate anions decreases.
\end{abstract}

Keywords: Allophane, Langmuir equation, Lawu, Merapi

\begin{abstract}
ABSTRAK
Alofan adalah mineral liat tanah dengan kapasitas adsorpsi fosfat yang tinggi melalui mekanisme pertukaran ligan. Penelitian ini bertujuan untuk membandingkan karakteristik adsorpsi fosfat oleh alofan yang berasal dari Gunung Merapi dan Gunung Lawu dalam kaitannya dengan sifat kimia dan mineralogi dari alofan tersebut. Hasil X-Ray Flourescence menunjukkan bahwa sampel alofan dari Gunung Merapi dan Lawu memiliki rasio Si/Al yang rendah, yaitu 1,18 (Merapi) dan 1,16 (Lawu). Karakteristik spektral inframerah dari alofan menunjukkan bahwa pita adsorpsi utama muncul pada kisaran 2700-3700 cm-1 (karena getaran semua gugus hidroksil $(\mathrm{OH})$ ), $1400-1800 \mathrm{~cm}^{-1}$ (getaran deformasi $\mathrm{HOH}$ ), $650-1200 \mathrm{~cm}^{-1}$ (getaran antara Si-O-Al). Percobaan adsorpsi fosfat pada alofan dilakukan pada konsentrasi adsorbat awal hingga 2,0 $\mathrm{mM}$ dan pada $\mathrm{pH}$ 4,0 dan 8,0. Adsorpsi fosfat pada alofan menunjukkan bahwa alofan dari Gunung Merapi dan Lawu dikategorikan sangat tinggi dalam mengadsorpsi fosfat dan sesuai dengan persamaan adsorpsi Langmuir. Adsorpsi fosfat meningkat dengan penurunan $\mathrm{pH}$ karena muatan positif seperti $\mathrm{Al}-\mathrm{OH}_{2}{ }^{+}$pada struktur alofan meningkat. Alasan lain adalah muatan negatif fosfat secara bertahap menurun dari -2 ke-1 dengan penurunan $\mathrm{pH}$, dan gaya tolak antara $\mathrm{Si}^{-} \mathrm{O}^{-}$yang bermuatan negatif dalam struktur alofan dan anion fosfat berkurang.
\end{abstract}

Kata Kunci: Alofan, Lawu, Merapi, persamaan Langmuir

\section{INTRODUCTION}

Andisols are soils derived from volcanic materials that contain high amounts of organic matter and

\footnotetext{
J Trop Soils, Vol. 25, No. 1, 2020: 39-46

ISSN 0852-257X; E-ISSN 2086-6682
}

short range aluminosilicate. In general, Andisols are predominated by amorphous materials such as Aloxides, Fe-oxides, allophane and imogolite (Hanudin et al. 2014). Allophane is a series name of naturally occurring amorphous hydrous aluminosilicates with various chemical compositions, which are characterized by the predominant $\mathrm{Si}$ - 
$\mathrm{O}-\mathrm{Al}$ bondings. Allophane is one of the reactive soil minerals because it has very large surface area and many active functional groups (Devnita, 2005). The properties of allophane surface include cation and anion exchange, the uptake of organic and inorganic compounds, and the source of acidity from silanol $(\mathrm{Si}-\mathrm{OH})$ and aluminol (Al-OH) functional groups (Reinert et al. 2011).

The important functional groups controlling the reactivity of allophane is alluminol (Al-OH) and silanol (Si-OH). Johan et al. (1997) indicated that alluminol plays an important role in adsorbing phosphate in soil. The conclusion has been reached that phosphate retention in allophanic soils is mainly due to the ability of allophane (amorphous aluminumsilicate of various $\mathrm{Al}$ to $\mathrm{Si}$ ratios) to strongly adsorb the phosphate specifically by ligand-exchange (Parfitt 1980).

Phosphorus (P) is an essential element determining plant growth and productivity. Due to $P$ fixation by soil colloidal surfaces, its availability in soil is rarely sufficient for optimum growth and development of plants (Malhotra et al. 2018). Besides nitrogen $(\mathrm{N})$, phosphorus $(\mathrm{P})$ is an essential nutrient for plant growth and productivity. Its concentration in plants ranges from $0.05 \%$ to $0.5 \%$ of total plant dry weight. Although the concentration of $\mathrm{P}$ in soil is 2000 -fold higher than that in the plant, its fixation in the form of aluminium/iron or calcium/ magnesium phosphates renders its availability for plant uptake. Hence, plants often face the problem of P deficiency in agricultural fields (Smith 2003). This study was conducted to understand the mechanism of phosphate adsorption on allophane in relation to its chemical and mineralogical properties.

\section{MATERIALS AND METHODS}

\section{Sample Preparation}

Two clay fractions that have high content of allophane obtained from two volcanic mountains in Indonesia were used in this study. Soil samples from Indonesia were taken from B Horizon from two volcanic soils in Indonesia, namely Mount Merapi,
Yogyakarta and Mount Lawu, Central Java. The separation of sand, silt, and clay fractions was carried out by ultrasonification at $28 \mathrm{kHz}$. The process resulted in the breaking and disintegration of some pseudo sand and pseudo silt into finer particles using high frequency sound wave. The prepared allophane samples were subjected to X-ray Flourescence, Xray diffractometry, and Fourier transform infrared spectroscopy. This study was conducted from January until December 2017 in the Laboratory of Soil Physics, Faculty of Agriculture, Gadjah Mada University, Yogyakarta and the Laboratory of Applied Chemistry for Environtmental Industry, Faculty of Agriculture, Ehime University, Matsuyama, Ehime, Japan.

\section{Adsorption Experiment}

Phosphate adsorption experiment was carried out for each $50 \mathrm{mg}\left(105^{\circ} \mathrm{C}\right.$ oven dry basis) of allophane sample. In single adsorbate system, an adsorbate solution containing phosphate $\left(\mathrm{NaH}_{2} \mathrm{PO}_{4}\right)$ was prepared by mixing it with $\mathrm{NaCl}$ solution. The solutions containing 0 to $2 \mathrm{mmol} \mathrm{L}^{-1}$ of $\mathrm{NaH}_{2} \mathrm{PO}_{4}$ and 0 to $2 \mathrm{mmol} \mathrm{L}^{-1}$ of $\mathrm{NaCl}$. Then demineralized water was added to the mixture so as to give a total volume of $100 \mathrm{ml}$. The initial phosphate concentration of the mixed solutions were varied from 0 to $2 \mathrm{mM}$. The total Na concentration of the mixed solutions were kept as 0 to $2 \mathrm{mM}$ by adjusting the amount of $\mathrm{NaCl}$ added. The $\mathrm{pH}$ of the mixture were adjusted to 4.0 and 8.0 by adding the diluted $\mathrm{HCl}$ or $\mathrm{NaOH}$ solution. The mixture was shaken for $20 \mathrm{hr}$, then centrifuged at $3500 \mathrm{rpm}$ for 15 minutes to separate the precipitated clay and supernatant. The supernatant was analyzed for $\mathrm{pH}$ with $\mathrm{pH}$ meter and the concentration of $\mathrm{P}$ was determined using ascorbic acid method (Murphy and Riley 1962). The amount of phosphate adsorbed was calculated from the difference between the initial and final (equilibrium) phosphate concentrations. The effect of $\mathrm{pH}$ on the adsorption of phosphate on allophane was also examined similarly in the single adsorbate system, in which the phosphate concentration was fixed at $1 \mathrm{mM}$ and $\mathrm{pH}$ of the adsorbate solution set to $2.0-8.0$.

Table 1. The results of XRF analysis on allophane from Mt. Merapi and Mt. Lawu.

\begin{tabular}{ccccc}
\hline Sample & $\begin{array}{c}\mathrm{SiO}_{2} \\
(\% \mathrm{w} / \mathrm{w})\end{array}$ & $\begin{array}{c}\mathrm{Al}_{2} \mathrm{O}_{3} \\
(\% \mathrm{w} / \mathrm{w})\end{array}$ & $\begin{array}{c}\mathrm{Fe}_{2} \mathrm{O}_{3} \\
(\% \mathrm{w} / \mathrm{w})\end{array}$ & $\begin{array}{c}\mathrm{Si} / \mathrm{Al} \\
\text { Ratio }\end{array}$ \\
\hline Merapi & 37.46 & 31.77 & 22.73 & 1.18 \\
Lawu & 34.63 & 29.67 & 24.80 & 1.16 \\
\hline
\end{tabular}


The adsorption data were plotted according to the Langmuir adsorption equation below:

$$
\mathrm{q}=\frac{\mathrm{kCb}}{1+\mathrm{kC}}
$$

The equation above can be converted into a simple regression equation below:

$$
\mathrm{C} / \mathrm{q}=1 / \mathrm{kb}+\mathrm{C} / \mathrm{b}
$$

In which $\mathrm{q}=$ amount of phosphate adsorbed; $\mathrm{k}=\mathrm{a}$ constant related to the binding energy; $b=$ maximum adsorption of phosphate; and $\mathrm{C}=$ equilibrium phosphate concentration.

\section{RESULTS AND DISCUSSION}

\section{Identification of Clay Samples}

\section{X-ray Flourescence Analysis}

$\mathrm{X}$-ray fluorescence is a well-established and powerful tool for nondestructive elemental analysis of almost all the elements present in a sample. It is widely used for environmental, industrial, pharmaceutical, forensic, and scientific research applications to determine the presence or absence and in some cases to measure the concentrations of elemental constituents or contaminants. The fluorescing atoms can be excited by energetic electrons, ions, or photons. The fluorescent X-rays are in general measured by two types of detection systems, namely wavelength dispersive detection (WDXRF) and energy dispersive detection (EDXRF) (Chen et al. 2008). The results of X-ray fluorescence analysis of Merapi and Lawu samples are presented in Table 1.

Table 1 shows that although the allophane sample from Mt. Merapi has slightly higher Si/Al ratio, both allophane from Mt. Merapi and Mt. Lawu

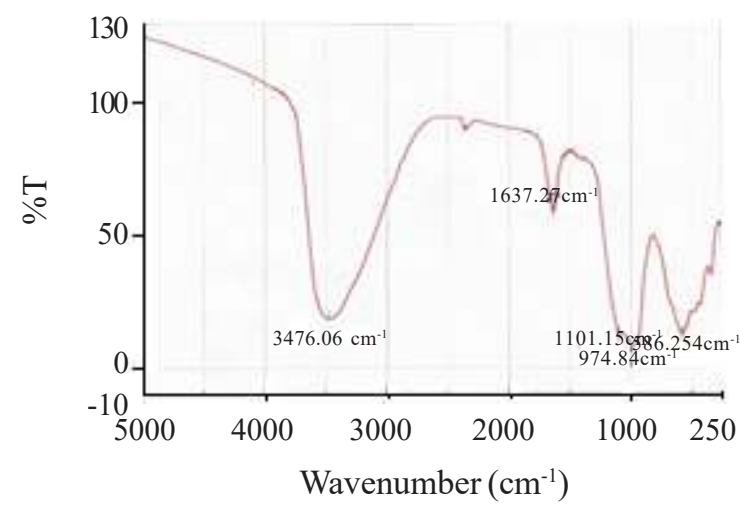

have low $\mathrm{Si} / \mathrm{Al}$ ratios. Allophane with lower $\mathrm{Si} / \mathrm{Al}$ ratio has higher adsorptivity for phosphate than allophane with higher $\mathrm{Si} / \mathrm{Al}$ ratio. This is ascribed to higher content of Al-OH and $\mathrm{Al}-\mathrm{OH}_{2}$ groups in the $\mathrm{Si} / \mathrm{Al}$ structure or higher $\mathrm{Al}$ content per unit mass. Aluminol groups, i.e. $\mathrm{Al}-\mathrm{OH}$ and $\mathrm{Al}-\mathrm{OH}_{2}$ are responsible for phosphate and organic anion adsorptions in soils and clay minerals (Jara et al. 2006).

\section{Fourier Transform Infrared Spectroscopy Analysis}

In infrared spectroscopy, infrared radiation is passed through a sample. Some of the infrared radiation is absorbed by the sample and some of it is passed through (transmitted). The resulting spectrum represents the molecular absorption and transmission, creating a molecular fingerprint of the sample. Like a fingerprint, no two unique molecular structures produce the same infrared spectrum. This makes the infrared spectroscopy useful for several types of analyses (Thermo 2001). Typically, there are four regions of types of bonds that can be analyzed from the Fourier Transform Infrared (FTIR) spectra (Mohamed et al. 2017).

The results of infrared spectrum identification are shown in Figure 1. The identification on allophane samples from both Mt. Merapi and Mt. Lawu show wide vibration at $2700-3700 \mathrm{~cm}^{-1}$ with the maximum absorption of $3476.06 \mathrm{~cm}^{-1}$. This occures due to stretching vibration of all hydroxyl $(\mathrm{OH})$ groups. In the hydroxyl stretch region (300$3500 \mathrm{~cm}^{-1}$ ), spectra are dominated by intense structure and less absorption due to H-bonded species (Bonelli et al. 2009). In the second region, vibration at $1400-1800 \mathrm{~cm}^{-1}$ with the peak at $1637.27 \mathrm{~cm}^{-1}$, in which the absorption refers to the vibration of $\mathrm{HOH}$ deformation (appearing from water uptake). Then, on the third region, vibration

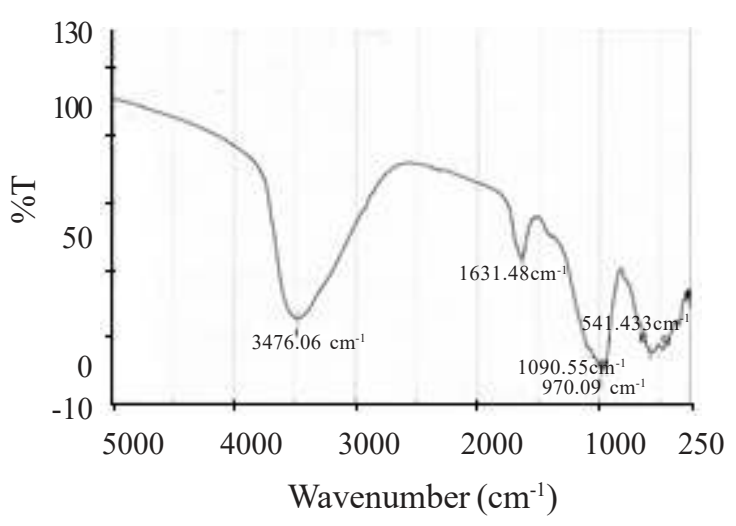

Figure 1. The results of IR spectrum analysis of allophane samples from a) Mt. Merapi and b) Mt. Lawu. 


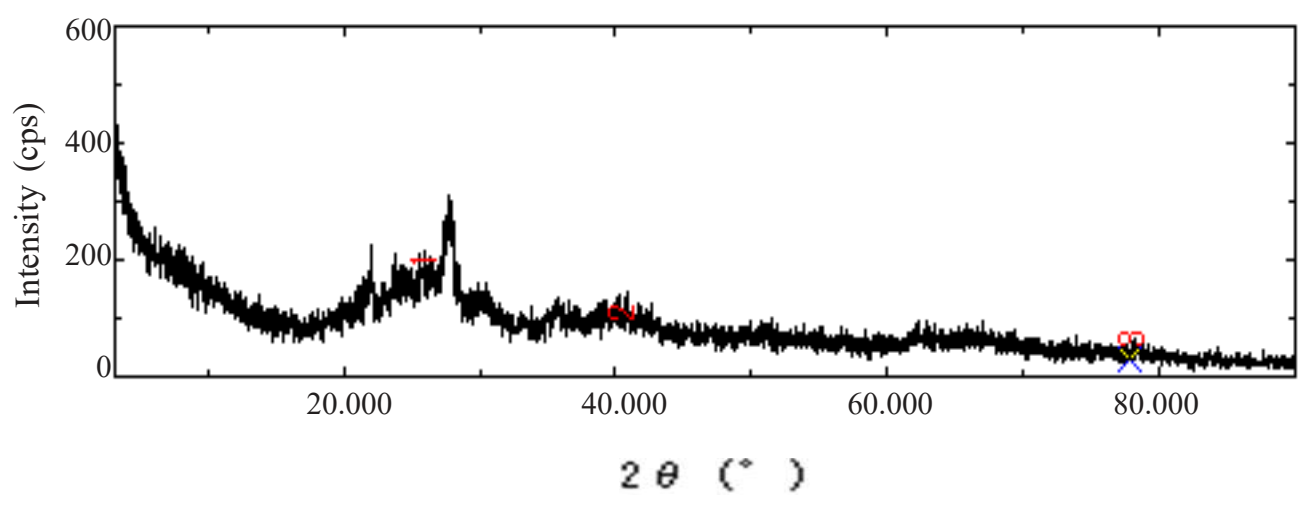

Figure 2. The X-ray diffraction patterns of the allophane sample from mount Merapi.

at $650-1200 \mathrm{~cm}^{-1}$ with the peak seen at 1101.15 $\mathrm{cm}^{-1}$. This occurs because of the vibration between the Si-O-Al. In the fourth region, the peak is seen at $586.254 \mathrm{~cm}^{-1}$, this happens because of the contribution of Al-O. This band is a common feature for both natural and synthesized allophane, indicating that allophane samples contain unique $\mathrm{Al}-\mathrm{OH}$ structures.

\section{X-ray Powder Diffraction Pattern}

Figure 2 shows the X-ray diffraction pattern for allophane sample from Mt. Merapi. The allophane showed three broad diffraction bands with intensities of strong, medium, and weak. The similar pattern is also shown in allophane sample from Mt. Lawu (Figure 3). Almost no differences in the bands between Merapi and Lawu samples were identified. The bands were similar to the former investigation (Johan 1999) and the recent study from some volcanic mountains in indonesia by Pranoto et al. 2013. However, there are some differences because of the impurities of the allophane samples used in this experiment. Farmer et al. 1977 suggested that the latter two bands are reflections of imogolite and might be ascribed to the imogolite structure because allophane and imogolite have some basic structure named gibbsite with one orthosilicate occupying the vacant site in its structure (Son et al. 1998).

\section{Phosphate Adsorption Isotherm}

Phosphate Adsorption Isotherm of Allophane from Mt. Merapi and Mt. Lawu

Figure 4 shows the adsorption isotherms of phosphate on allophane from Merapi and Lawu samples at different initial $\mathrm{pH}$ values (4.0 and 8.0). The isotherms for Merapi samples indicated that the amount of phosphate adsorbed on the allophane increased with increasing equilibrium solution concentration. The increase is sharp at lower equilibrium $P$ concentration, then the curves gradually become nearly flat at higher equilibrium phosphate concentration. All of the isotherms in Figure 4 fit well to the Langmuir equation with $\mathrm{R}^{2}$ more than 0.9 (Table 2).

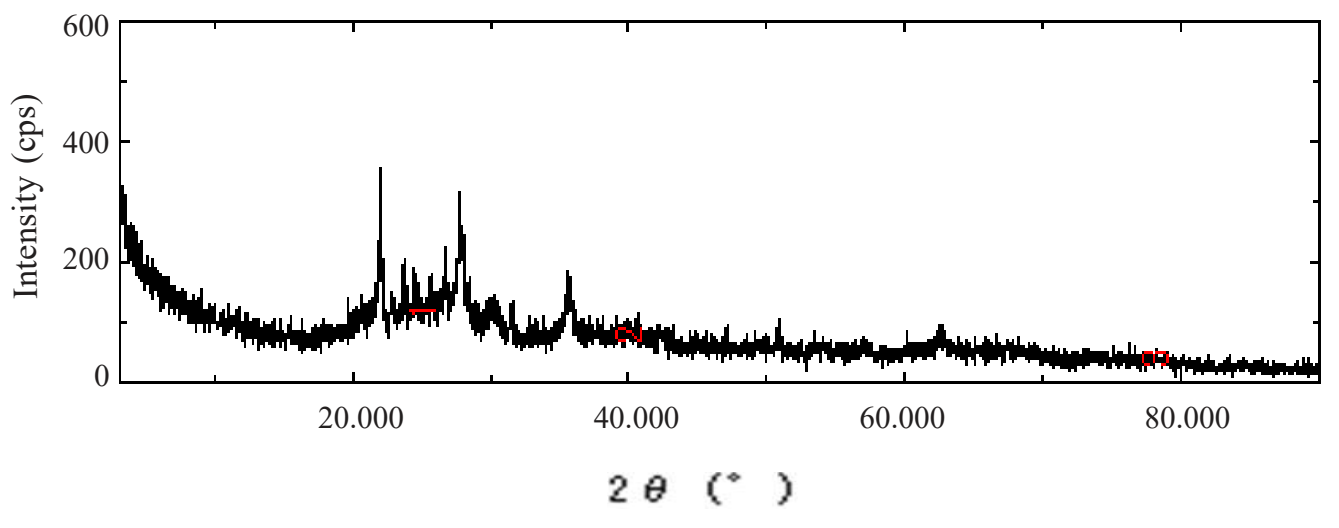

Figure 3. The X-ray diffraction patterns of the allophane sample from mount Lawu. 


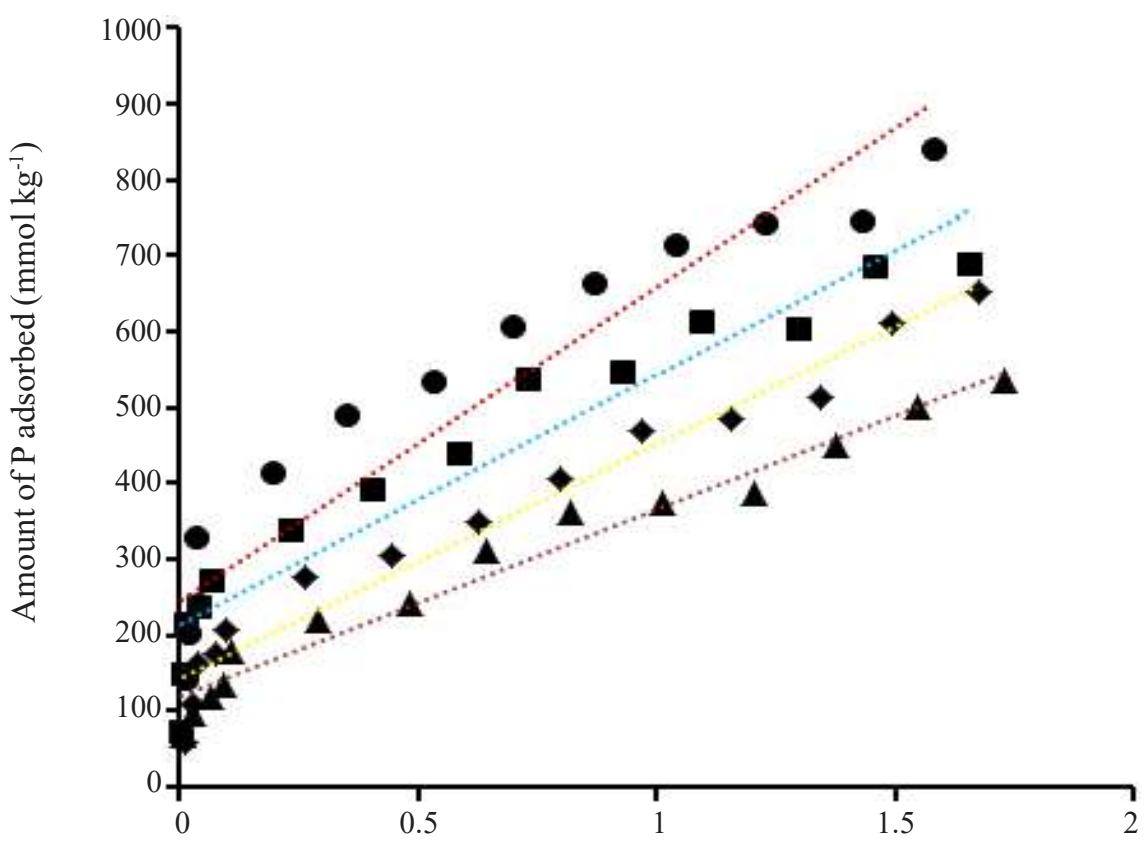

Equilibrium $\mathrm{P}$ concentration $\left(\mathrm{mmol} \mathrm{L}^{-1}\right)$

Figure 4. Phosphate adsorption isotherm of allophane from Mt. Merapi and Mt.

Lawu. : Merapi pH 4, : Lawu pH 4, $\mathbf{\bullet}$ : Merapi pH 8, $:$ Lawu pH 8, ............. : Linear (Merapi pH 4), ............ : Linear (Lawu pH 4), ............ Linear (Merapi pH 8), ……... : Linear (Lawu pH 8).

Figure 4 shows that the allpohane from Mt. Lawu has higher adsorptivity than the allophane from Mt. Merapi. This is ascribed to the higher content of $\mathrm{Al}-\mathrm{OH}$ and $\mathrm{Al}-\mathrm{OH}_{2}$ groups in the structure of allophane from Mt. Lawu, because allophane from Lawu sample has lower $\mathrm{Si} / \mathrm{Al}$ ratio or higher $\mathrm{Al}$ content per unit mass than Merapi sample (Table 1). Aluminol groups, i.e. $\mathrm{Al}-\mathrm{OH}$ or $\mathrm{Al}-\mathrm{OH}_{2}$ are responsible for phosphate and organic anion adsorptions in soils and clay minerals (Jara et al. 2006). In the structure of allophane, the aluminol groups are only located at the pores of the wall of the hollow spherules (Henmi and Huang 1985). Fundamental structure of allophane is considered to be lower $\mathrm{Si} / \mathrm{Al}$ ratio, allophane that has higher $\mathrm{Si} / \mathrm{Al}$ ratio has an excess of $\mathrm{Si}$ atoms accessorily attached to the fundamental structure (Henmi et al. 1997). The excess of Si atoms may also be adsorbed onto the aluminol groups, causing less aluminol groups or adsorption sites for phosphate and oxalate on Merapi sample.

In acid condition, Al-OH creates positive charge on the soil due to entrancing $\mathrm{H}^{+}$ions on octahedral layer of $\mathrm{Al}(\mathrm{OH})_{3}$ (Masduqi 2004). The phenomenon could be written as follow:

$$
\begin{aligned}
& \mathrm{Al}(\mathrm{OH})_{3}+\mathrm{H}^{+} \longrightarrow \mathrm{Al}(\mathrm{OH})_{3} \ldots \mathrm{H}^{+} \\
& \mathrm{Al}(\mathrm{OH})_{3} . . \mathrm{H}^{+}+\mathrm{H}_{2} \mathrm{PO}_{4}^{-} \longrightarrow \mathrm{Al}(\mathrm{OH})_{3} \cdot \mathrm{H}_{3} \mathrm{PO}_{4}
\end{aligned}
$$<smiles>[1H][18O]P(=O)(O)O</smiles>

$\underset{\text { phosphoric acid }}{\mathrm{H}_{3} \mathrm{PO}_{4}} \mathrm{pK}_{\mathrm{a1}}=2.148$<smiles></smiles><smiles>O=P([O-])([O-])O</smiles><smiles>C1CCCCC1</smiles><smiles>O=P([O-])([O-])[O-]</smiles>

$\mathrm{PO}_{4}^{3-}$ $\underset{\text { monohydrogen phosphate }}{\mathrm{HPO}_{4}^{-} \quad \mathrm{pK}_{\mathrm{a}}=12.35}$ phosphate (tribasic)

Figure 5. Changes in phosphate forms. 


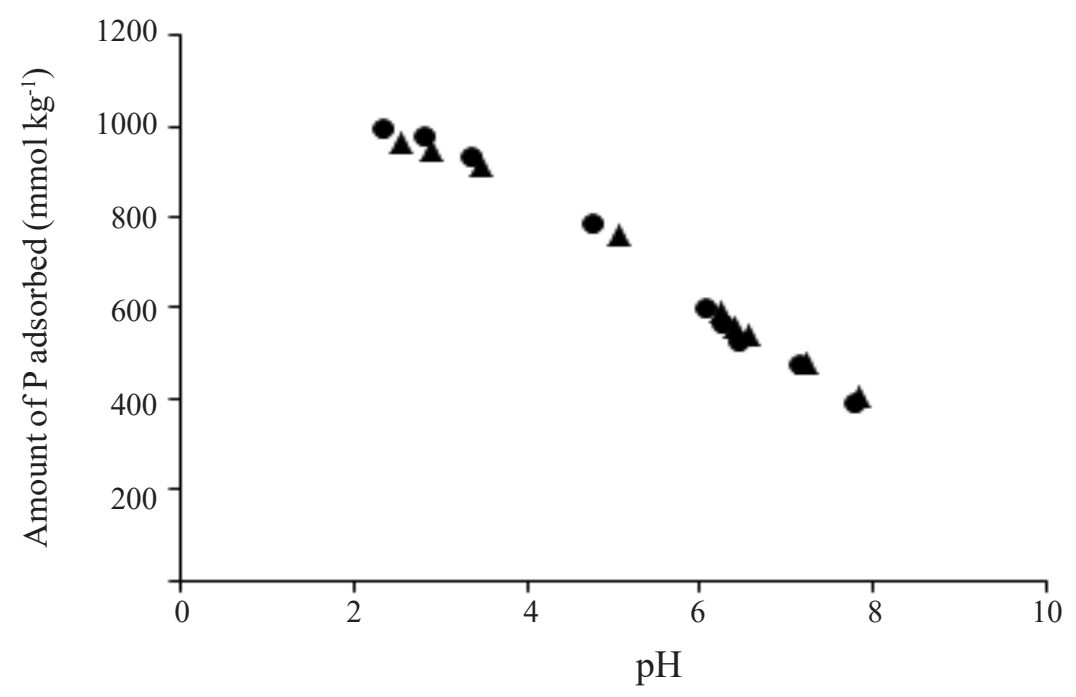

Figure 6. Adsorption isotherm of phosphate in different pH levels. $\bullet$ : Lawu, $\mathbf{\wedge}$ : Merapi.

Based on the above equation it was indicated that in acid condition ( $\mathrm{pH} 4)$, phosphate ion is adsorbed by allophane through electrostatic bond, which form an outersphere complex. The complex formed can likely be exchanged by other anions. On the other hand, under $\mathrm{pH} 8$ condition, the $\mathrm{P}$ adsorption phenomenon might have occurred through a ligand exchange mechanism with a reaction as follow:

$$
\mathrm{Al}(\mathrm{OH})_{3}+\mathrm{H}_{2} \mathrm{PO}_{4}^{-} \longrightarrow \mathrm{Al}(\mathrm{OH})_{2} \mathrm{H}_{2} \mathrm{PO}_{4}+\mathrm{OH}^{-}
$$

Phosphate ion adsorbed by amorphous materials via ligand exchange mechanism forms an innersphere complex (Hanudin et al. 2014).

\section{Effect of pH on Phosphate Adsorption}

Figure 6 shows the effect of $\mathrm{pH}$ on $\mathrm{P}$ adsorption on allophane from Merapi and Lawu samples at a constant initial phosphate concentration of $1 \mathrm{mM}$. In case of phosphate adsorption, the

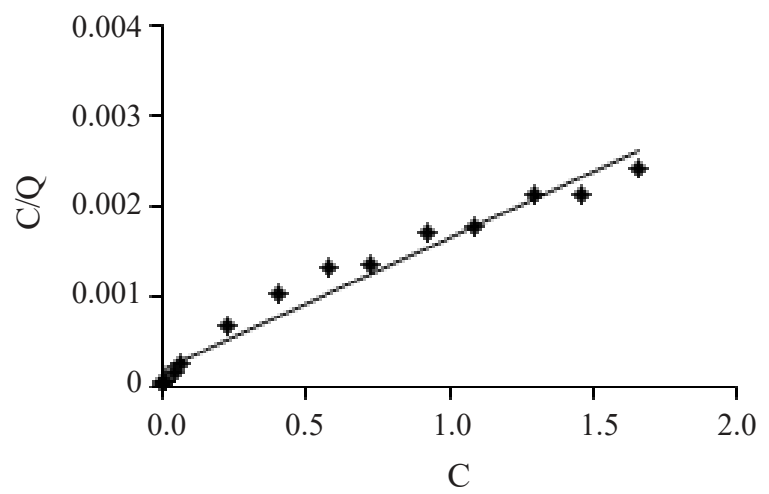

amount of adsorption increased linearly with decreasing $\mathrm{pH}$.

The negative charge of phosphate gradually decreases from -2 to -1 with decreasing $\mathrm{pH}$, and the repulsive force between negatively charged $\mathrm{Si}$ $\mathrm{O}^{-}$in the allophane structure and phosphate anions decreases. The changes in phosphate forms are described in Figure 5.

\section{Langmuir Adsorption Equation}

The phosphate adsorption data were plotted according to the Langmuir adsorption equation. Langmuir adsorption isotherm is often used to establish maximum adsorption and $\mathrm{P}$ bond energy in soil. Langmuir adsorption isoterm is used when there is a uniform pitch and the same adsorption energy across the adsorption pattern. Figure 7 and 8 show the straight lines that obtained for all cases, up to equilibrium phosphate concentration of 1.5 to $1.7 \mathrm{mM}$.

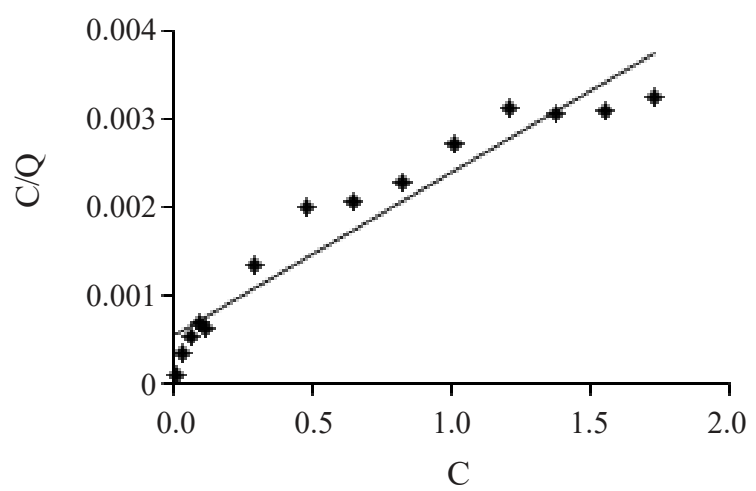

Figure 7. Langmuir isotherm for adsorption of phosphate by the allophane from mount Merapi at (a) $\mathrm{pH} 4$ and (b) $\mathrm{pH}$ 8. C: equilibrium $\mathrm{P}$ concentration ( $\left.\mathrm{mmol} \mathrm{L}^{-1}\right)$, Q: amount of $\mathrm{P}$ adsorbed $\left(\mathrm{mmol} \mathrm{kg}^{-1}\right)$. 

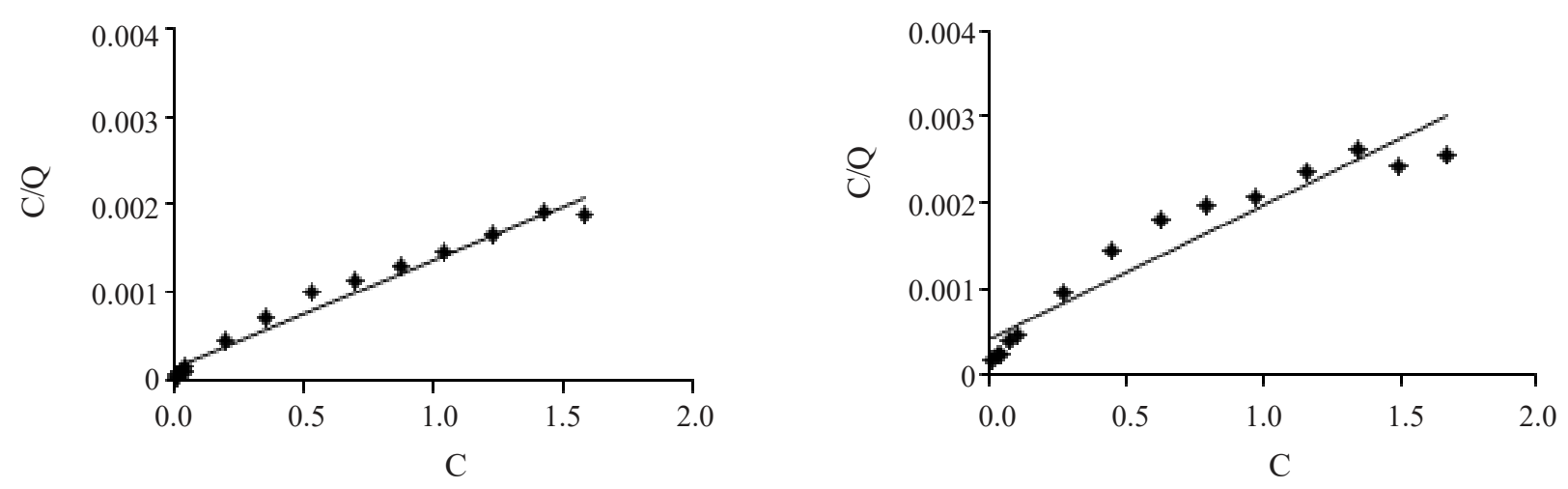

Figure 8. Langmuir isotherm for adsorption of phosphate by the allophane from mount Lawu at (a) $\mathrm{pH} 4$ and (b) $\mathrm{pH}$ 8. C: equilibrium $\mathrm{P}$ concentration $\left(\mathrm{mmol} \mathrm{L}^{-1}\right)$, Q: amount of $\mathrm{P}$ adsorbed $\left(\mathrm{mmol} \mathrm{kg}^{-1}\right)$.

Table 2. Langmuir parameters for phosphate adsorption on allophane.

\begin{tabular}{lcrr}
\hline \multirow{2}{*}{ Sample } & \multirow{2}{*}{ Parameter } & \multicolumn{2}{c}{$\mathrm{pH}$} \\
\cline { 3 - 4 } & & \multicolumn{1}{c}{8} \\
\hline Merapi & $\mathrm{b}$ & 714.29 & 555.56 \\
& $\mathrm{k}$ & 7.00 & 3.00 \\
\multirow{3}{*}{ Lawu } & $\mathrm{R}^{2}$ & 0.96 & 0.92 \\
& $\mathrm{~b}$ & 833.33 & 666.67 \\
& $\mathrm{k}$ & 12.00 & 3.75 \\
& $\mathrm{R}^{2}$ & 0.97 & 0.92 \\
\hline
\end{tabular}

In Table 2, the coefficient determination $\left(\mathrm{R}^{2}\right)$ of allophane from both Mount Merapi and Mount Lawu either at $\mathrm{pH} 4$ and $\mathrm{pH}$ is between 0.92 - 0.97 , all results fit well to Langmuir equation. The b values at $\mathrm{pH} 4$ are 714.29 and 833.33 for the Merapi and Lawu sample, respectively, whereas at $\mathrm{pH} 8$ the values are 555.56 and 666.67 for the Merapi and Lawu sample, respectively. The constant related to the binding energy $(\mathrm{k})$ at $\mathrm{pH} 4$ were 7.00 and 12.00 for the Merapi and Lawu sample, respectively, whereas at $\mathrm{pH} 8$, the values are 3.00 and 3.75 for the Merapi and Lawu sample, respectively. From the regression equation it can be seen that the value of $\mathrm{k}$ indicates adsorption capacity. Adsorption capacity is a parameter that can describe the $\mathrm{P}$ adsorption on allophane, the higher the $\mathrm{k}$ value, the higher the adsorption capacity of $\mathrm{P}$ is. The $\mathrm{k}$ values at $\mathrm{pH} 8$ in both samples are lower than the $\mathrm{k}$ values at $\mathrm{pH} 4$. This phenomenon is due to the amount of adsorption increases linearly with decreasing $\mathrm{pH}$, the negative charge of phosphate gradually decreases from -2 to -1 with decreasing $\mathrm{pH}$, and the repulsive force between negatively charged $\mathrm{Si}$ $\mathrm{O}^{-}$in the allophane structure and phosphate anions decreases.

The $\mathrm{k}$ value for Lawu sample is higher compared to that for Merapi sample, indicating that the Lawu sample has higher adsorptivity than Merapi sample. This phenomenon is ascribed to higher content of $\mathrm{Al}-\mathrm{OH}$ and $\mathrm{Al}-\mathrm{OH}_{2}$ groups in the structure of allophane from Lawu sample, because the Lawu sample has lower $\mathrm{Si} / \mathrm{Al}$ ratio or higher $\mathrm{Al}$ content per unit mass than Merapi has. Aluminol groups including $\mathrm{Al}-\mathrm{OH}$ or $\mathrm{Al}-\mathrm{OH}_{2}$ are responsible for phosphate and organic anion adsorptions in soils and clay minerals.

\section{CONCLUSIONS}

Allophane samples from the two volcanic mountains of Merapi and Lawu are categorized as very high in adsorbing phosphate anions and fit well with the Langmuir adsorption equation. Phosphate adsorption on allophane is affected by the $\mathrm{Si} / \mathrm{Al}$ ratio, the lower the $\mathrm{Si} / \mathrm{Al}$ ratio is, the higher the phosphate adsorption will be. Infrared spectral characteristics of the allophane materials indicated that the main adsorption bands appeared at the range of 2700$3700 \mathrm{~cm}^{-1}$ (due to stretching vibration of all hydroxyl $(\mathrm{OH})$ groups), $1400-1800 \mathrm{~cm}^{-1}$ (vibration of $\mathrm{HOH}$ deformation), and $650-1200 \mathrm{~cm}^{-1}$ (vibration between the Si-O-Al). Phosphate adsorption increases with decreasing $\mathrm{pH}$ due to the mechanisms below: a) Positive charge sites such as $\mathrm{Al}-\mathrm{OH}_{2}^{+}$in the 
allophane structure increases with decreasing $\mathrm{pH}$, and the positive sites attract phosphate anions. b) The negative charge of phosphate gradually decreases from -2 to -1 with decreasing $\mathrm{pH}$, and the repulsive force between negatively charged $\mathrm{Si}$ $\mathrm{O}^{-}$in the allophane structure and phosphate anions decreases.

\section{ACKNOWLEDGEMENTS}

The authors thank the Six University Initiative Japan-Indonesia (SUIJI) Joint Degree Program for supporting the facilities and funding the research.

\section{REFERENCES}

Bonelli B, I Bottero, N Ballarini, S Passeri, F Cavani and E Garrone. 2009. IR Spectroscopic and catalytic characterization of the acidity of imogolite-based systems. J Catal 264: 15-30.

Chen ZW, WM Gibson and H Huang. 2008. High definition X-Ray fluorescence: Principles and techniques. X-Ray Optics and Instrumentation. Volume 2008, Article ID 318171, 10 pages doi:10.1155/ 2008/31817.

Farmer VV, AR Fraser, JD Russel and N Yoshinaga. 1977. Recognition of imogolite structures in allophanic clays by infrared spectroscopy. Clay miner 12: 55-57.

Hanudin E, ST Sukmawati, B Radjagukguk and NW Yuwono. 2014. The Effect of humic acid and silicic acid on $\mathrm{P}$ adsorption by amorphous mineral. Procedia Env Sci 20: 402-409.

Henmi T and PM Huang. 1985. Effect of phosphate anion on the formation of imogolite. In: LG Schultz, H Van Olphen and FA Mumpton (eds). Proceedings of the 8th International Clay Conference, Denver. The Clay Minerals Society, Bloomington, Indiana, pp. 231-236.

Henmi T, N Matsue and E Johan. 1997. Change in the surface acidity of allophane with low $\mathrm{Si} / \mathrm{Al}$ ratio by the reaction with ortho-silicic acid. Jpn $J$ Soil Sci Plant Nutr 68: 514-520 (in Japanese with English abstract)
Jara AA, A Violante, M Pigna and ML Mora. 2006. Mutual interactions of sulfate, oxalate, citrate and phosphate on synthetic and natural allophones. Soil Sci Soc Am J 70: 337-346.

Johan E. 1999. Adsorption of Phosphate on Nano-Ball Allophane, Change in Charge Characteristic Induced by the Adsorption, and Mechanism Analysis by Molecular Orbital Method. Dissertation. Ehime University. Japan.

Johan E, N Matsue and T Henmi. 1997. Phosphate adsorption on nano-ball allophone and its molecular orbital analysis. Clay Sci 10:259-270.

Malhotra H, Vandana, S Sharma and R Pandey. 2018. Phosphorus nutrition: Plant growth in response to deficiency and excess. In: M Hasanuzzaman, M Fujita, H Oku, K Nahar and B Hawrylak-Nowak (eds). Plant Nutrients and Abiotic Stress Tolerance. Springer, Singapore, pp 171-190.

Masduqi A. 2004. Reduction of phosphate compound in artificial waste water by haloisite soil as adsorbent. Faculty of Enginering, Surabaya Technology Institute. Surabaya. Indonesia

Mohamed MA, J Jaafar, AF Ismail, MHD Othman and MA Rahman. 2017. Fourier Transform Infrared (FTIR) Spectroscopy. Universiti Teknologi Malaysia, Johor Bahru, Johor, Malaysia.

Murphy J and JP Riley. 1962. A Modified single solution method for the determination of phosphate in natural waters. Anal Chim Acta 27: 31-36.

Parfitt RL. 1980. Chemical properties of variable charge soils. In: BKG Theng (ed). Soils with Variable Charge. New Zealand Society of Soil Science, pp. 167-194.

Reinert L, F Ohashi, M Kehal, J-L Bantignies, C GozeBac and L Duclaux. 2011. Characterization and boron adsorption of hydrothermally synthesised allophanes. Appl Clay Sci 54: 274-280.

Smith VH. 2003. Eutrophication of freshwater and coastal marine ecosystems: a global problem. Environ Sci Pollut Res 10: 126-139.

Son LT, N Matsue and T Henmi. 1998. Boron adsorption on allophane with nano-ball morphology. Clay Sci 10:315-325. 